\title{
A new Fe304/CuO/AC Nanocomposite for Imidacloprid Removal: Characterization, Optimization, and Adsorption Modeling
}

Amrollah Parsaie ( $\sim$ parsaee.a52@gmail.com )

Payame Noor University https://orcid.org/0000-0001-7067-2900

Nadereh Rahbar

Ahvaz Jundishapur University of Medical Sciences

Mohamadreza Baezat

Payame Noor University

\section{Research Article}

Keywords: Imidacloprid, Neonicotinoids, Magnetic adsorbent, Fe3O4 nanoparticles, CuO nanoparticles, activated carbon

Posted Date: July 15th, 2021

DOl: https://doi.org/10.21203/rs.3.rs-712774/v1

License: (c) (1) This work is licensed under a Creative Commons Attribution 4.0 International License. Read Full License 


\title{
A new $\mathrm{Fe}_{3} \mathrm{O}_{4} / \mathrm{CuO} / \mathrm{AC}$ nanocomposite for Imidacloprid removal: Characterization, optimization, and adsorption modeling
}

\author{
Amrollah Parsaie ${ }^{1, *}$, Mohammad Reza Baezat ${ }^{1}$, Nadereh Rahbar ${ }^{2}$ \\ ${ }^{1}$ Department of Chemistry, Payame Noor University, Tehran, Iran \\ ${ }^{2}$ Nanotechnology Research Center, School of Pharmacy, Ahvaz Jundishapur University of Medical Sciences, Ahvaz, Iran \\ * Corresponding author: Amrullah Parsaei, Department of Chemistry, Payame Noor University, Tehran, Iran \\ Tel: 09166089854 \\ E-mail address: Parsaee.a52@gmail.com
}




\section{Abstract}

A new magnetic adsorbent $\left(\mathrm{Fe}_{3} \mathrm{O}_{4} / \mathrm{CuO} / \mathrm{AC}\right)$ composed of magnetite $\left(\mathrm{Fe}_{3} \mathrm{O}_{4}\right)$ and copper oxide $(\mathrm{CuO})$ nanoparticles Impregnated with activated carbon $(\mathrm{AC})$ has been fabricated and used for the first time to remove imidacloprid (IMCP) insecticide from the aqueous solutions. This composite was characterized using field emission scanning electron microscopy, Fourier transform infrared spectroscopy, x-ray diffraction, energy dispersive x-ray diffraction, and vibrating sample magnetometer. The main influential factors such as the solution $\mathrm{pH}$, the adsorbent amount, temperature, agitating time, and initial pesticide concentration were also tested to evaluate the optimized condition. Based on the results obtained from isotherm and kinetic modeling, the adsorption mechanism of IMCP on $\mathrm{Fe}_{3} \mathrm{O}_{4} / \mathrm{CuO} / \mathrm{AC}$ is a combination of physisorption and chemisorption phenomena. The experimental data fitted best to the Freundlich isotherm model revealing the presence of heterogeneous sites for IMCP adsorption. Besides, the kinetics results revealed that the adsorption process well fitted with pseudosecond-order model, implying that the chemisorption was determining step in adsorption process. Thermodynamic results showed the spontaneous and exothermic nature of the adsorption process. Under optimal conditions ( $\mathrm{pH} 7$; contact time, $10 \mathrm{~min}$; initial pesticide concentration, $10 \mathrm{mg} \mathrm{L}^{-1}$ ), IMCP removal efficiency was $99.6 \%$, indicating the excellent ability of $\mathrm{Fe}_{3} \mathrm{O}_{4} / \mathrm{CuO} / \mathrm{AC}$ nanocomposite for the adsorption of this pesticide from water solutions.

Keywords: Imidacloprid, Neonicotinoids, Magnetic adsorbent, $\mathrm{Fe}_{3} \mathrm{O}_{4}$ nanoparticles, $\mathrm{CuO}$ nanoparticles, activated carbon. 


\section{Introduction}

Imidacloprid (IMCP) with chemical name of [1-(6-chloro-3-pyridylmethyl)-Nnitroimidazolidin-2-ylideneamine] (Fig. 1) is a member of neonicotinoids as a relatively new class of insecticides which are widely used for control of sucking and chewing insects including aphids, thrips, plant hoppers, diamondback moths, and whiteflies. They act via binding to postsynaptic nicotinic receptors in the central nervous system of insect $(1)(2,3)$. IMCP is utilized for insects control in various crops such as cereals, maize, vegetables, citrus fruit and pome fruit, because of its high effectiveness and low toxicity to mammalian. However, due to the extensive consumption of the IMCP in agricultural production, its high solubility in water (500 mg $\mathrm{L}^{-1}$ ), and half-life in soil is (48-190 days), occurring of its residues in surface waters and plant foods can pose a serious risk to human health because of their interactions with acetylcholinesterase receptors and proteins (2, 4-7). Besides, recent studies showed that IMCP and other neonicotinoids represent the significant risk to honeybees, aquatic beings, and birds (8-10). They are categorized in persistent contaminants, and therefore, they can transport into aquatic ecosystems through drainage of agricultural areas (10). The levels of neonicotinoids, especially IMCP, have been monitored in some countries including Netherlands with highest reported concentration of $0.32 \mathrm{mg} \mathrm{L}^{-1}$ (11-14). The maximum residual levels of these insecticides in honey and other related products have been announced by the European Union in the range of 50 to $200 \mu \mathrm{g} \mathrm{kg}^{-1}$ (15).

During the past decade, a number of methods such as membrane process (16), ionexchange (17), chemical precipitation (18), coagulation-flocculation (19), photocatalytic reduction (20), biological (21), and adsorption (22) methodologies have been exploited for the removal of contaminants from the polluted water bodies. However, most of these methods have high operational costs, chemical consumption, and sludge production as well as low efficiency (23-25). Among these methodologies, the adsorption strategy has been widely exploited for the treatment of various contaminated food and environmental samples. This process is proven as suitable method for the removal of pollutants including pesticides, heavy metals, and other poisons from water solutions (26-28).

So far, some strategies have been developed for the removal of neonicotinoids including biopurification (29), microbial degrading (30), oxidation processes (31), and adsorption 
technique (6). The use of adsorption process in order to remove these pesticides from polluted water solutions was rarely reported $(6,7,32)$. However, some efforts has been performed for the extraction and/or preconcentration procedures of neonicotinoids (including IMCP) using an adsorbent via solid phase extraction (SPE) method $(5,15,33-$ $38)$,

Activated carbon is known as standard and effective adsorbent for the purification of municipal and industrial wastewaters for more than decades $(22,28,39)$. However, its turbidity creation and separation from effluents in removal process is a challenging issue. In this regard, cost-effective, simple and rapid separation of $\mathrm{Fe}_{3} \mathrm{O}_{4}$ (magnetite) nanopatricles as a biocompatible adsorbent introduces it as a suitable candidate for composite formation with activated carbon to solve the turbidity problem $(38,40)$. The easy separation of the magnetic adsorbent from aqueous solution is simply performed using an external magnetic field (41). On the other hand, owing to the presence of amine groups in IMCP molecule, the attraction between copper and these groups can be exploited by the use of $\mathrm{CuO}$ nanoparticles in the fabrication of the effective adsorbent $(1,42)$. Therefore, the scope of current work, is to focus on the development of new effective adsorbent namely $\mathrm{Fe}_{3} \mathrm{O}_{4} / \mathrm{CuO} / \mathrm{AC}$ nanocomposite due to the important role of the adsorbent materials in adsorption process. Copper oxide nanoparticles, activated carbon, and magnetite nanoparticles were selected to increase the selectivity, adsorption power, and the easy separation of the adsorbent from solution, respectively. This new nanocomposite was used to effective removal of IMCP from water solutions.

\section{Experimental}

\subsection{Reagents and standards}

All the used chemicals were of analytical grade. All the solutions were prepared using the double distilled water (DDW) throughout the experiments. Standard of IMCP and copper (II) oxide (nanopowder) were obtained from Merck Company (Germany). Iron (III) chloride anhydrous, iron (II) chloride tetrahydrate, hydrochloric acid solution ( $\mathrm{HCl})$, sodium hydroxide $(\mathrm{NaOH})$, and methanol were obtained from Samchun chemicals company (Korea). Activated carbon powder was obtained from Sigma-Aldrich. $100 \mathrm{mg} \mathrm{L}^{-1}$ stock solution of IMCP was used to prepare the standard solutions with different concentrations.

\subsection{Apparatus}


A Perkin Elmer UV-VIS double beam spectrophotometer was applied to record the UV-Vis absorbance measurements and spectra. A Bruker spectrometer (model Tensor 27, Germany) was used to obtain Fourier transform infrared (FT-IR) spectra. The magnetic properties of the synthesized $\mathrm{Fe}_{3} \mathrm{O}_{4}$ nanoparticles and $\mathrm{Fe}_{3} \mathrm{O}_{4} / \mathrm{CuO} / \mathrm{AC}$ nanocomposite were recorded using a MDK-VSM instrument (Meghnatis Daghigh Daneshpajouh Co., Iran). The morphology and elemental composition of nano-composite were evaluated by Field Emission Scanning Electron Microscope (FESEM) and Energy Dispersive X-ray Diffraction (EDX) using a Tescan model Mira3-XMU instrument (Czech Republic). The pattern of the nanocomposite X-ray diffraction (XRD) was recorded using an X'Pert Pro MPD instrument (PANalytical, Netherlands). The $\mathrm{pH}$ values were adjusted by use of a Metrohm pH-meter model 623 (Switzerland).

\subsection{Synthesis of $\mathrm{Fe}_{3} \mathrm{O}_{4}$ nanoparticles}

The co-precipitation of $\mathrm{Fe}$ (II) and $\mathrm{Fe}$ (III) chloride as the iron oxides $\left(\mathrm{FeO}\right.$ and $\mathrm{Fe}_{2} \mathrm{O}_{3}$ ) in the presence of ammonia solution was exploited for the preparation of $\mathrm{Fe}_{3} \mathrm{O}_{4}$ nanoparticles at room temperature as described previously (25). In brief, $5 \mathrm{~mL}$ of a solution composed of $\mathrm{Fe}(\mathrm{II})$ and $\mathrm{Fe}(\mathrm{III})$ with 1:2 molar ratio, was vigorously stirred while $50 \mathrm{~mL}$ of ammonium hydroxide solution $(1.5 \mathrm{M})$ was added drop-wisely. A black suspension identified the formation of magnetite nanoparticles. The mixture was stirred at $500 \mathrm{rpm}$ for another 10 min at this condition. An external magnetic field was applied to collect $\mathrm{Fe}_{3} \mathrm{O}_{4}$ nanoparticles. Then, the collected nanoparticles were thoroughly washed with DDW to eliminate excess ammonia and dried in oven at $80^{\circ} \mathrm{C}$.

\subsection{Preparation of $\mathrm{Fe}_{3} \mathrm{O}_{4} / \mathrm{CuO} / \mathrm{AC}$ magnetic adsorbent}

$1 \mathrm{~g}$ of each $\mathrm{CuO}$ and $\mathrm{Fe}_{3} \mathrm{O}_{4}$ nanoparticles were mixed with $0.5 \mathrm{~g}$ of $\mathrm{AC}$ powder and suspended in $50 \mathrm{ml}$ of DDW, homogeneously. After adjusting the suspension $\mathrm{pH}$ at 8 by use of $\mathrm{HCl}$ and $\mathrm{NaOH}$ solutions, it was heated to $80^{\circ} \mathrm{C}$ for ten min. Then the prepared nanocomposite was dried at $80{ }^{\circ} \mathrm{C}$ in oven.

\subsection{Design of IMCP adsorption experiments}

For the adsorption studies the batch procedure was used. A beaker containing $10 \mathrm{~mL}$ of IMCP solution was used in all the removal experiments. The effects of some influencing experimental parameters including $\mathrm{pH}$ of solution, the adsorbent amount, contact time, 
temperature, and initial pesticide concentration were examined on the performance of adsorption.

\subsection{1. pH effect}

To check the effect of $\mathrm{pH}$ on the adsorption process, $5 \mathrm{mg}$ of the adsorbent was mixed with $10 \mathrm{~mL}$ of $10 \mathrm{mg} \mathrm{L}^{-1} \mathrm{IMCP}$ solutions in the $\mathrm{pH}$ range of 4-10. By additions of dilute $\mathrm{NaOH}$ or $\mathrm{HCl}$ solutions, the $\mathrm{pH}$ value of the suspension remained constant throughout the removal process. The mixture was stirred at room temperature $\left(20{ }^{\circ} \mathrm{C}\right)$ with the rate of 500 rpm for $5 \mathrm{~min}$.

\subsubsection{The effect of adsorbent amount}

The influence of the adsorbent amount on the adsorption was examined with $10 \mathrm{mg} \mathrm{L}^{-1}$ IMCP solutions $(10 \mathrm{~mL})$ containing 2-30 $\mathrm{mg}$ of the adsorbent at $\mathrm{pH} \mathrm{7}$, and agitating at room temperature $\left(20^{\circ} \mathrm{C}\right)$ with the rate of $500 \mathrm{rpm}$ for $5 \mathrm{~min}$.

\subsubsection{The influence of contact time}

For kinetic studied, $20 \mathrm{mg}$ of the adsorbent with $10 \mathrm{mg} \mathrm{L}^{-1} \mathrm{IMCP}$ solutions (10 mL) at $\mathrm{pH}$ 7 were mixed. The suspensions were shaken at room temperature $\left(20{ }^{\circ} \mathrm{C}\right)$ in the fixed intervals including $1,2,5,10,20,30,40,50,60$, and 90 min with the rate of $500 \mathrm{rpm}$.

\subsubsection{The influence of initial concentration of IMCP on adsorption}

The effect of initial concentration of the pesticide on adsorption equilibrium was studied by mixing $20 \mathrm{mg}$ of the adsorbent and IMCP solutions $(10 \mathrm{~mL})$ with varying initial concentrations in the range of 5 to $30 \mathrm{mg} \mathrm{L}^{-1}$. These prepared suspensions were stirred for $10 \mathrm{~min}$ at $\mathrm{pH}=7$ and $20{ }^{\circ} \mathrm{C}$ with the rate of $500 \mathrm{rpm}$.

\subsection{Analysis of IMCP}

In all adsorption experiments, after separating of the adsorbent by the external magnetic field, IMCP concentration in solution was measured by spectrophotometry at the maximum wavelength of the analyte $(270 \mathrm{~nm})$. The UV-Vis. spectrum of IMCP was obtained within the wavelength region from 200 to $350 \mathrm{~nm}$ for the selection of maximum wavelength. The spectra related to IMCP solution before and after agitating with $\mathrm{Fe}_{3} \mathrm{O}_{4} / \mathrm{CuO} / \mathrm{AC}$ are depicted in Fig. 2. In each adsorption experiment, the removal 
efficiency and the equilibrium adsorption capacity were obtained by the following equations:

$\operatorname{Removal}(\%)=\frac{\mathrm{C}_{0}-\mathrm{C}_{\mathrm{e}}}{\mathrm{C}_{0}} \times 100$

$\operatorname{Removal}(\%)=\frac{\mathrm{C}_{0}-\mathrm{C}_{\mathrm{e}}}{\mathrm{m}} \times \mathrm{V}$

where $\mathrm{C}_{0}$ and $\mathrm{C}_{\mathrm{e}}\left(\mathrm{mg} \mathrm{L}^{-1}\right)$ are IMCP initial and equilibrium (residual) concentrations, respectively. In equation $(2), \mathrm{q}_{\mathrm{e}}\left(\mathrm{mg} \mathrm{g}^{-1}\right), \mathrm{m}(\mathrm{g})$, and $\mathrm{V}(\mathrm{L})$ are the adsorption capacity, adsorbent amount, and solution volume, respectively. All the experiments were conducted in triplicate, and the mean values of the measurements were reported as results.

\subsection{Modeling of the adsorption process: isotherms and kinetics}

To design a proper adsorption unit, the kinetic studies showing the removal rate of poison from the aqueous solutions is necessary. For modeling the adsorption process of IMCP on $\mathrm{Fe}_{3} \mathrm{O}_{4} / \mathrm{CuO} / \mathrm{AC}$, four common and widely used kinetic models including pseudo-firstorder, pseudo-second-order, intra-particle diffusion, and Elovich were exploited. The linear equations of these models are given in Table 1.

Generally, the adsorption behavior of molecules onto the surface of adsorbent is revealed by the isotherm studies. In this way, to fit the experimental data of adsorption process, four common theoretical isotherm models including Freundlich, Langmuir, Temkin, and Dubinin-Radushkevich (D-R) were examined. The parameters and equations related to these models are presented in Table 2 .

\subsection{The influence of temperature on adsorption}

To check the temperature influence on the equilibrium of adsorption, a series of experiments was performed by mixing $20 \mathrm{mg}$ of the adsorbent with $10 \mathrm{mg} \mathrm{L}^{-1}$ IMCP solutions $(10 \mathrm{~mL})$ at $\mathrm{pH} 7$. The suspensions were shaken for 10 min with the rate of 500 $\mathrm{rpm}$ at the temperature range of $20-60^{\circ} \mathrm{C}$.

\section{Results and Discussion}

\subsection{Characteristics of $\mathrm{Fe}_{3} \mathrm{O}_{4} / \mathrm{CuO} / \mathrm{AC}$ nanocomposite}

As can be seen from Fig. 3A, FESEM image of the prepared $\mathrm{Fe}_{3} \mathrm{O}_{4}$ nanoparticles shows the diameter distribution of around $25 \mathrm{~nm}$ with spherical shape. Moreover, Fig. 3B shows the 
morphology of nanocomposite with the large number of cavities, and the presence of a mixture of metal nanoparticles and layered carbon particles. The EDX spectrum of $\mathrm{Fe}_{3} \mathrm{O}_{4} / \mathrm{CuO} / \mathrm{AC}$ (Fig. 3C) exhibits the peaks for iron, copper, carbon, and oxygen indicating the successful synthesis of the adsorbent.

As can be seem from Fig. 4A, the FTIR spectra of $\mathrm{Fe}_{3} \mathrm{O}_{4}$ nanoparticles, $\mathrm{Fe}_{3} \mathrm{O}_{4} / \mathrm{CuO} / \mathrm{AC}$ nanocomposite, IMCP, and $\mathrm{Fe}_{3} \mathrm{O}_{4} / \mathrm{CuO} / \mathrm{AC} @ \mathrm{IMCP}$ are obtained in the wavenumber range of $400-4000 \mathrm{~cm}^{-1}$. The strong and sharp peak at $576.82 \mathrm{~cm}^{-1}$ can be related to the $\mathrm{Fe}-\mathrm{O}$ vibration in $\mathrm{Fe}_{3} \mathrm{O}_{4}$ nanoparticles (Fig. 4A-a) (43). The strong absorption peaks in Fig. 4A-b at $576.12 \mathrm{~cm}^{-1}$ (with some shoulders) and $3433.99 \mathrm{~cm}^{-1}$ can be ascribed to the vibrations of metal oxide bands $(\mathrm{Fe}-\mathrm{O}$ and $\mathrm{Cu}-\mathrm{O})$, and $\mathrm{O}-\mathrm{H}$ band of surface adsorbed water molecules in $\mathrm{Fe}_{3} \mathrm{O}_{4} / \mathrm{CuO} / \mathrm{AC}$ nanocomposite, respectively. Fig. 4A-c presents the nanocomposite spectrum after adsorption of IMCP revealing almost the all characteristic peaks of the constituents with slight shift due to physicochemical mechanism of the adsorption process. These shits can be seen in metal oxide $\left(579.13 \mathrm{~cm}^{-1}\right)$ and $\mathrm{N}-\mathrm{H}$ or $\mathrm{O}-\mathrm{H}$ vibrations (3412.53 $\left.\mathrm{cm}^{-1}\right)$.

XRD pattern of $\mathrm{Fe}_{3} \mathrm{O}_{4} / \mathrm{CuO} / \mathrm{AC}$ nanocomposite in position at $40 \mathrm{kV}$ and $30 \mathrm{~mA}$ with $\mathrm{Cu}$ anode over the 20: 4-70 is presented in Fig. 4B. The diffraction peaks related to $\mathrm{Fe}_{3} \mathrm{O}_{4}$, $\mathrm{CuO}$, and $\mathrm{AC}$ in this XRD spectrum indicated the successful synthesis of the adsorbent without any phase change.

A vibrating sample magnetometer (VSM) was exploited to study the magnetic properties of $\mathrm{Fe}_{3} \mathrm{O}_{4}$ and $\mathrm{Fe}_{3} \mathrm{O}_{4} / \mathrm{CuO} / \mathrm{AC}$ nanocomposite. As seen in Fig. $4 \mathrm{C}$, the super-paramagnetic property of the prepared $\mathrm{Fe}_{3} \mathrm{O}_{4}$ and $\mathrm{Fe}_{3} \mathrm{O}_{4} / \mathrm{CuO} / \mathrm{AC}$ was indicated by the absence of magnetic hysteresis loops in their curves, (44). Furthermore, the saturation magnetization of Fe3O4 (69.1 emu g ${ }^{-1}$ ) was higher than that $\mathrm{Fe}_{3} \mathrm{O}_{4} / \mathrm{CuO} / \mathrm{AC}$ (42.8 emu g $\mathrm{e}^{-1}$ ), revealing the existence of non-magnetic $\mathrm{CuO}$ and $\mathrm{AC}$ in the nanocomposite structure. Despite the reduction in the magnetic property, this adsorbent was efficiently and rapidly eliminated from aqueous solutions using a magnet due to its relatively high saturation magnetization value.

\subsection{Experimental conditions}

\subsubsection{The influence of $\mathrm{pH}$}


In adsorption studies, the solution $\mathrm{pH}$ is of vital importance in the ionization and surface charge of adsorbent functional groups. The influence of solution $\mathrm{pH}$ on the removal efficiency of IMCP (section 2.5.1) is presented in Fig. 5a. As seen, the adsorption efficiency (removal percentage) of IMCP increases substantially with increase in the solution $\mathrm{pH}$ from 4.0 to 7.0, and then decreases in higher $\mathrm{pH}$ values. According to these results, the maximum percent of IMCP removal (56.0\%) was achieved at $\mathrm{pH}$ value of 7.0 , and the adsorbent exhibits the best function neutral media. This observation is in agreement with the other reports which show the maximum adsorption potential of IMCP in $\mathrm{pH} 7$ probably owing to its neutral molecular structure in this $\mathrm{pH}(5,15,37,38)$. At acidic media the lower uptake of adsorbent may be related to the protonation of the amine groups of IMCP molecules as well as surface of magnetite and $\mathrm{CuO}$ nanoparticles of the adsorbent. This phenomenon, on one hand, reduces the tendency between IMCP and the adsorbent because of the electrostatic repulsion between the moieties with positive charges, and on the other hand, a vigorous competition between proton ions and the poison takes place for the adsorption on the active sites of the adsorbent $(24,25)$. However, the observed decrease in the removal rate at alkaline environments $(\mathrm{pH}>7)$ might be correlated to the existence of the large number of hydroxide ions and their competition with IMCP for the active sites of the adsorbent. Considering the maximum removal of IMCP, $\mathrm{pH} 7$ was chosen for the subsequent experiments.

\subsubsection{The effect of adsorbent amount}

The influence of adsorbent amount on the adsorption extent of IMCP on $\mathrm{Fe}_{3} \mathrm{O}_{4} / \mathrm{CuO} / \mathrm{AC}$ nanocomposite was tested in the range of $2-30 \mathrm{mg}$ under conditions that is described in section 2.5.2. As depicted in Fig. 5b, the uptake of IMCP enhances with by increasing the adsorbent quantity and the removal percentage reaches to $96.7 \%$ using $20 \mathrm{mg}$ of the adsorbent. Besides, the removal trend shows direct relationship with the adsorbent amount up to $20 \mathrm{mg}$ which means that the greater surface area and more active sites provide the adsorption with more efficiency at fixed IMCP initial concentration. Thereafter, increasing the adsorbent dosage cannot cause further adsorption and thus, the removal rate levels off. The aggregation of $\mathrm{Fe}_{3} \mathrm{O}_{4} / \mathrm{CuO} / \mathrm{AC}$ particles at higher amounts and therefore, the lower usage of the adsorbent active sites might be the reasons for this observed phenomenon (25). Based on these results, $20 \mathrm{mg}$ of $\mathrm{Fe}_{3} \mathrm{O}_{4} / \mathrm{CuO} / \mathrm{AC}$ nanocomposite was chosen as the optimal adsorbent amount for further tests. 


\subsubsection{Kinetic modeling: contact time effect}

At optimal conditions of $\mathrm{pH}$ and the adsorbent amount, the influence of stirring time on the adsorption efficiency was evaluated at $90 \mathrm{~min}$ period as describes in section 2.5.3. As can be observed from Fig. 6a, the equilibrium state and nearly the complete removal of IMCP (99.6\%) from the test solution take place in the first10 min. This rapid increase in the removal percentage in the initial contact times and reaching to equilibrium state in very short time can be explained in the context of fast kinetic of adsorption reaction (fast occupation) and saturation of reactive sites of the adsorbent. The previous studies have reported the similar trends $(26,45)$. According to the findings, the subsequent experiments were carried out in the optimum contact time of $10 \mathrm{~min}$. Besides, based on these experiments, the plots and parameters of four widely used kinetic models including pseudofirst-order, pseudo-second-order, intra-particle diffusion, and Elovich were obtained and are given in Fig. $6 \mathrm{~b}$ and Table 3. In Table 3, $\mathrm{q}_{\mathrm{t}}$, is the adsorption capacity at a given time $\mathrm{t}$, and $\mathrm{q}_{1}$, and $\mathrm{q}_{2}$ are the adsorption capacity at equilibrium state at pseudo-first-order and pseudosecond-order kinetic models, respectively. The rate constants of pseudo-first-order, pseudosecond-order, and intra-particle diffusion kinetic models are $\mathrm{K}_{1}, \mathrm{~K}_{2}$, and $\mathrm{K}_{\mathrm{ip}}$ are, respectively.

Firstly, the correlation coefficients $\left(\mathrm{R}^{2}\right)$ obtained from the linear form of equations related to the kinetic models (Figs S1-S4) were compared with each other. Then, the highest value of $\mathrm{R}^{2}$ was used to choose the most proper kinetic model fitting the IMCP adsorption on $\mathrm{Fe}_{3} \mathrm{O}_{4} / \mathrm{CuO} / \mathrm{AC}$ nanocomposite. As can be seen from Table 3, the $\mathrm{R}^{2}$ obtained for the pseudo-second-order kinetic model $\left(\mathrm{R}^{2}=0.9991\right)$ is the highest compared to the other models, indicating that this model has a better fit with the adsorption of IMCP on the adsorbent. The plots of various kinetic models (Fig. 6b), also confirms that the experimental data of IMCP adsorption onto $\mathrm{Fe}_{3} \mathrm{O}_{4} / \mathrm{CuO} / \mathrm{AC}$ nanocomposite is in agreement with the pseudo-second order model, implying that the determining step is chemisorption. Furthermore, the calculated $\mathrm{q}_{2}$, cal. value $\left(5.076 \mathrm{mg} \mathrm{g}^{-1}\right.$ ) is closer to the experimental $\mathrm{q}_{\mathrm{e}}$, exp. $\left(4.688 \mathrm{mg} \mathrm{g}^{-1}\right)$ than those of the other models, which is another confirmation for this model. According to this finding it can be concluded that the adsorption on IMCP onto the adsorbent is performed by chemisorption $(27,46,47)$. The adsorption process probably involves the electron sharing between IMCP molecules via nitrogen free electrons and the binding sites of the adsorbent, specially, $\mathrm{CuO}$ nanoparticles (23). 
The other models showed lower $\mathrm{R}^{2}$ values revealing their lesser role in the removal process. Besides, for intra-particle diffusion model the value of $\mathrm{C}_{\mathrm{i}}>0$ indicates that linear parts of the curve $\left(q_{t}\right.$ vs. $\left.t^{0.5}\right)$ do not pass through the origin (Table 3 ). This observation reveals that although this model can control the adsorption process to some extent by diffusion in boundary layer, but is not the only rate-controlling step $(24,47,48)$.

\subsubsection{Isotherm modeling: IMCP initial concentration effect}

The effect of initial concentrations of IMCP ranging from 5-30 $\mathrm{mg} \mathrm{L}^{-1}$ on its adsorption by $\mathrm{Fe}_{3} \mathrm{O}_{4} / \mathrm{CuO} / \mathrm{AC}$ (section 2.5.4) is depicted in Fig. 7a. As seen, the removal efficiency decreases by increasing IMCP concentration from $99.7 \%$ to $67.1 \% \mathrm{mg} \mathrm{L}^{-1}$ for 5 and $30 \mathrm{mg}^{-1}$, respectively, probably owing to the fixed number of active sites on the adsorbent as reported in previous studies (24). However, the adsorption capacity increases with the rise in initial IMCP concentration due to the increase of its adsorption per mass unit of the adsorbent (from 2.47 to $14.61 \mathrm{mg} \mathrm{g}^{-1}$ ). This observation might be owing to the increase of the driving force to overcome the mass transfer resistance of IMCP molecules between the solid and aqueous phases (45).

Under the optimal conditions, the linear equations of four isotherm models including Freundlich, Langmuir, Temkin, and D-R were used to explain the adsorption of IMCP in the concentration range of 5-30 $\mathrm{mg} \mathrm{L}^{-1}$ (Figs S5-S8). The obtained graphs for these isotherm models and also values for the equilibrium isotherm parameters are presented in Fig. $7 \mathrm{~b}$ and Table 4. In this Table, $\mathrm{K}_{\mathrm{L}}, \mathrm{K}_{\mathrm{F}}$, and $\mathrm{K}_{\mathrm{T}}$ are Langmuir, Freundlich, and Temkin constants, respectively. Besides, in D-R model, $\varepsilon\left(\mathrm{kJ} \mathrm{mol}^{-1}\right)$ is the Polanyi potential and can be determined via $\varepsilon=\mathrm{RT} \ln \left(1+(1 / \mathrm{Ce})\right.$ equation. The $\mathrm{q}_{\mathrm{m}}, \mathrm{n}, \mathrm{R}_{\mathrm{L}}$, and $\mathrm{E}$ parameters are the maximum adsorption capacity, Freundlich adsorption heterogeneity factor, the separation parameter, and the mean free energy of adsorption, respectively (48).

As shown in Fig. $7 \mathrm{~b}$ and Table 4, based on the $\mathrm{R}^{2}$ values, the isotherm models are fitted to the experimental results in the following order: Freundlich $>$ Langmuir $>$ Temkin $>$ D-R. The correlation coefficient of 0.9924 for Freundlich model suggests the presence of heterogamous conditions in adsorption process.

Langmuir and Freundlich isotherms show the single-layer (homogeneous) and multi-layer (heterogeneous) mechanisms of the adsorption process, respectively. In addition, the indirect 
interactions between the adsorbent and the adsorbate are considered in Temkin model, and D-R isotherm model shows a surface area with the homogeneous adsorption energy $(25,49)$.

In D-R model the $\mathrm{E}$ value of is obtained by use of the following equation:

$\mathrm{E}=\frac{1}{\sqrt{-2 \mathrm{D}}}$

The desirability of IMCP adsorption onto the adsorbent was studied using $\mathrm{R}_{\mathrm{L}}\left(1 /{ }\left(1+\mathrm{C}_{0}\right.\right.$ $\mathrm{K}_{\mathrm{L}}$ )) as a dimensionless parameter which is derived from Langmuir model (Table 4). Generally, the adsorption process will be favorable if $\mathrm{R}_{\mathrm{L}}$ lies within 0 and $1\left(0<\mathrm{R}_{\mathrm{L}}<1\right)$. For $\mathrm{R}_{\mathrm{L}}=0, \mathrm{R}_{\mathrm{L}}>1$, and $\mathrm{R}_{\mathrm{L}}=1$, the adsorption is irreversible, unfavorable, and linear, respectively (49). A favorable behavior of IMCP onto the adsorbent surface was confirmed by the $R_{L}$ value $(0.060)$ as shown in Table 4 .

The $1 / \mathrm{n}$ value in Freundlich model shows the favorability of IMCP adsorption on $\mathrm{Fe}_{3} \mathrm{O}_{4} / \mathrm{CuO} / \mathrm{AC}$. The small value of $1 / \mathrm{n}(0.318)$, between 0 and 1 , and the large value of $\mathrm{K}_{\mathrm{F}}$ $\left(5.974 \mathrm{mg} \mathrm{g}^{-1}\right)$ confirms the effective adsorption of IMCP molecules on the adsorbent.

The $\mathrm{E}$ value in D-R model gives an idea about either chemical or physical adsorption according to its magnitude. With the E values of $8-16 \mathrm{~kJ} \mathrm{~mol}^{-1}$ the mechanism of adsorption can be chemical process, while with the values of $\mathrm{E}<8 \mathrm{~kJ} \mathrm{~mol}^{-1}$ shows that the physical adsorption mechanism is predominant (24). As can be seen from Table 4, the E value for IMCP adsorption on $\mathrm{Fe}_{3} \mathrm{O}_{4} / \mathrm{CuO} / \mathrm{AC}\left(4.784 \mathrm{~kJ} \mathrm{~mol}^{-1}\right.$ ) was found to be lower than $8 \mathrm{~kJ} \mathrm{~mol}^{-1}$, indicating that the dominant mechanism is the physical adsorption. Generally, in adsorption process, the chemisorption mechanism is the slowest step, while the physisorption is the main mechanism in the system, as mentioned before (section 3.2.3) (25).

\subsubsection{Determination of the thermodynamic parameters: the effect of temperature}

The effect of solution temperature was studied in the range of $20-60{ }^{\circ} \mathrm{C}$ under conditions described in section 2.7, and the optimal temperature for IMCP adsorption as well as the related thermodynamic parameters was obtained. The results revealed that in the temperatures higher than $20^{\circ} \mathrm{C}$, the removal efficiencies of IMCP slow down, gradually, showing that the lower temperatures are favorable in adsorption process (Fig. S9). The thermodynamic parameters including standard entropy change standard enthalpy change $\left(\Delta \mathrm{H}^{0}, \mathrm{kJmol}^{-1}\right),\left(\Delta \mathrm{S}^{0}, \mathrm{kJmol}^{-1} \mathrm{~K}^{-1}\right)$, and Gibbs energy $\left(\Delta \mathrm{G}^{0}, \mathrm{kJmol}^{-1}\right)$ were calculated from Van't Hoff equation (50): 
In Eq. (4), $\mathrm{R}$ is the gas constant $\left(8.3145 \mathrm{Jmol}^{-1} \mathrm{~K}^{-1}\right)$, and distribution coefficient of $\mathrm{K}_{\mathrm{d}}$ (Eq. 5) is the ratio of the adsorbed IMCP concentration $\left(\mathrm{C}_{\mathrm{s}}\right)$ to the aqueous phase IMCP concentration $\left(\mathrm{C}_{\mathrm{e}}\right)$ at the defined temperature $(\mathrm{T})$ at equilibrium state $(51)$.

$$
\mathrm{K}_{\mathrm{d}}=\frac{\mathrm{C}_{\mathrm{s}}}{\mathrm{C}_{\mathrm{e}}}
$$

The $\Delta \mathrm{G}$ value was calculated by use of Eq. (4). In addition, $\Delta \mathrm{H}^{0}$ and $\Delta \mathrm{S}^{0}$ values were determined using slope and intercept of $\ln K_{d}$ versus $1 / T$ plot from another form of Van't Hoff equation according to Eq. (6), respectively (Fig. S10).

$$
\ln \mathrm{K}_{\mathrm{d}}=\frac{\Delta \mathrm{S}^{\circ}}{\mathrm{R}}-\frac{\Delta \mathrm{H}^{\circ}}{\mathrm{RT}}
$$

In Table 5 the calculated parameters and their values are presented. As seen, all the three values of thermodynamic parameters $\left(\Delta \mathrm{H}^{0}, \Delta \mathrm{S}^{0}\right.$, and $\left.\Delta \mathrm{G}^{0}\right)$ are negative in standard condition $\left(25^{\circ} \mathrm{C}\right.$ and $1 \mathrm{~atm}$ pressure). The negative $\Delta \mathrm{H}^{0}$ value indicates the exothermic behavior of the adsorption process and describes the decrease in the sorption ability of the adsorbent with an increase in the solution temperature. Furthermore, the negative value of $\Delta \mathrm{S}^{0}$ confirms the affinity of the adsorbent for IMCP, and also, reveals that the randomness decreased at the solid-solution interface during the sorption phenomenon. As seen from Table 5 , the $\Delta \mathrm{G}$ value for all the examined temperatures is negative demonstrating the spontaneous nature of adsorption process. Besides, with an increase in the temperature, the value of $\Delta \mathrm{G}^{0}$ increases indicating that lower temperatures are favorable for the IMCP adsorption and the enhancing in temperature reduces the spontaneity of the removal reaction. According to $\Delta \mathrm{G}^{0}$ value, the adsorption process is categorized to chemisorption (-80 to $\left.-400 \mathrm{~kJ} \mathrm{~mol}^{-1}\right)$ or physisorption $(0$ to $-20 \mathrm{~kJ} \mathrm{~mol}^{-1}$ ). From Table 5, it can be concluded that the sorption process has a physical nature $\left(\Delta \mathrm{G}^{0}=-7.756 \mathrm{~kJ}\right.$ mol-1), and the physical adsorption is the mechanism is predominant in this system. This result is consistant with the data documented in Table 4, as E value refers to the physisorption phenomenon.

\section{Conclusion}

Herein, a selective and effective approach for IMCP elimination from water solutions has been developed with the removal efficiency of about $99 \%$ by use of $\mathrm{Fe} 3 \mathrm{O} 4 / \mathrm{CuO} / \mathrm{AC}$ via 
adsorption process. The experimental results showed that operating factors such as initial concentration of IMCP, $\mathrm{pH}$, temperature, and adsorbent amount remarkably influence on the adsorption efficiency. $\mathrm{Fe}_{3} \mathrm{O}_{4} / \mathrm{CuO} / \mathrm{AC}$ nanocomposite exhibited a better performance with the initial concentration level of $10 \mathrm{mg} \mathrm{L}^{-1}$ and $25^{\circ} \mathrm{C}$ at $\mathrm{pH} 7$. The optimum contact time of 10 min implied that the adsorption process reaches the equilibrium state in very short time which can be related to the high tendency of the adsorbent to IMCP. The pseudo-secondorder kinetic model and Freundlich isotherm model were consistent with the adsorption process. According to these results it was proved that both chemisorption and physisorption mechanisms were involved in the adsorption process. The synthesized adsorbent presented the high saturation magnetization (42.8 emu/g), demonstrating its rapid and easy isolation from water solution. This inexpensive adsorbent composed of metal oxides nanoparticles and activated carbon showed rapid removal process in soft conditions in terms of $\mathrm{pH}$ and temperature with the high adsorption performance, and the excellent capability for water remediation.

\section{Declarations}

Funding: The authors are grateful for the supports of this work by Research Council of Shiraz Payame Noor University.

Competing interests: The authors declare that they have no conflict of interest.

\section{References}

1. Y . Xiangdong, L. Xiaolei, Q. Bin, Y. Yuying, Z. Yuanyuan, L.Shiying, R. Honglin, L. Zengshan, L. Mingyuan \& Y. Zhou. Food Agric Immunol . 30, 432-445(2019).

2. A. Djurovi, S. Kravic, N. Grahovac, V. Bursic,S.Kravic, Z. Suturovic. Int J Anal Chem. 11, 5138491( 2016).

3. M. Pirsaheb, S. Pourhaghighat, M. Shamsipur, K. Sharafi. LWT - Food Science and Technology. 60, 825831( 2015)

4. X. Cao, G. Liu, Y. She, Z. Jiang, F. Jin, M. Jin, RSC Advances. 114,113144-51(2016).

5. M. Mahramanlioglu,M.Zahoor.Chem Biochem Eng Q. 25,55-63 (2011).

6. M. Socias-Viciana, E. Gonzalez-Pradas,M. Saifi, MD.Urena-Amate, F. Flores-Cespedes, M. FernandezPerez. Pest Manag Sci. 59,1162-1168, ( 2003) 
7. A .Tapparo, D.Marton, C . Giorio, A .Zanella, L .Solda, M. Marzaro. Environ Sci Technol. 46,2592-2599. (2012).

8. A. Lopez-Antia, M. E.Ortiz-Santaliestra, F .Mougeot, R. Mateo. Environ Res.136,97-107( 2015).

9. C.A. Morrissey, P. Mineau, J.H.Devries, F. Sanchez-Bayo, M. Liess, M.C. Cavallaro,K.Liber, Environ Int.74,291-303 (2015).

10.T.C V. Dijk ,M.A. V. Staalduinen,J.P . V. d. Sluijs. PloS one.9, e89837 (2013).

11. A.Daraghmeh, A. Shraim, S. Abulhaj, R. Sansour, J.C. Ng. Environ Geochem Health. 20,929-934 (2007).

12. K. Starner, K.S. Goh. Bull Environ Contam Toxicol. 88,316-321 (2012).

13. D.P. Weston, D. Chen, M.J. Lydy. Sci Total Environ.18-25,527-528 ( 2015).

14. H. Ding,R.Wang, W.Liu,S.Cheng,W.Ji,Z.Zeng,X.Wang, Mikrochim. 186(2),103 ( 2019).

15. S.Velizarov, J.Crespo, M.A. Reis. ev Environ Sci Biotechnol,3(4),361-380(2005)

16. J. Charles, C.Bradu, N. Morin-Crini, B .Sancey, P. Winterton, G. Torri, Saudi Chemical Society.20,185194( 2013)

17. A. Pohl. Water Air Soil Pollut. 503 , 231(10)( 2020)

18. Y. Sun, S .Zhou, P-C. Chiang, K.J. Shah. Water-Energy Nexus. 2(1),25-36(2019).

19. Z .Zhao, H. An, J. Lin, M. Feng, V. Murugadoss, T .Ding . Chemical record. 19(5),873-882 ( 2019).

20. G. Rodríguez-Castillo, M. Molina-Rodríguez, JC. Cambronero-Heinrichs, JP. Quirós-Fournier, V. LizanoFallas, C .Jiménez-Rojas. Chemosphere.235,1097-1106(2019)

21. N.K .Hamadi, S .Swaminathan, X.D. Chen. J Hazard Mater.112(1-2),133-141 ( 2004)

22. A .Azari, B. Kakavandi, R.R .Kalantary, E .Ahmadi, M .Gholami, Z .Torkshavand.M.Azizi, Journal of Porous Materials.22(4),1083-1096( 2015)

23. M .Ahmadi, M. Foladivanda, N .Jaafarzadeh, Z. Ramezani, B .Ramavandi, S. Jorfi. Research and Technology - Aqua.66(2),116-130(2017)

24. M. Omidinasab, N . Rahbar, M. Ahmadi, B. Kakavandi, F .Ghanbari ,G.Z. Kyzas . Environ Sci Pollut Res Int

.Dec.25, 34262-34276(2018)

25. J. Yang, Y .Dong, J .Li, Z .Liu, F. Min, Li Y. Korean J Chem Eng.32(11),2247-2256 (2015).

26. A.Jonidi. Jafari, B. Kakavandi, R.Rezaei. Kalantary, H. Gharibi, A .Asadi, A .Azari.A.A.Babaei, Korean J Chem Eng.33(10),2878-2890(2016).

27. A. Mandal, N .Singh. Int J Hyg Environ Health. 220 ,637- 645 ( 2017).

28. G. Rodriguez-Castillo, M.Molina-Rodriguez, M.Perez-Villanueva, M .Masis-Mora, CE. RodriguezRodriguez, Bull Environ Contam Toxicol. 101,137-143 (2018).

29. G .Rodriguez-Castillo, M. Molina-Rodriguez, J.C. Cambronero-Heinrichs, J.P .Quiros-Fournier, V. LizanoFallas, C. Jimenez-Rojas, Chemosphere.235,1097-1106 (2019)

30. T. Gonzalez, J.R. Dominguez, S .Correia,Int J Environ Waste Manag. 261,110156 (2020) 
31. N. Daneshvar, S .Aber, J Food Agric Environ.5, 425-429 (2007).

32. H. Obana,M.Okihashi, K.Akutsu, Y. Kitagawa, S.Hori ,J Agric Food Chem.9,2501-2505(2003)

33. Q.Zahou, Y.Ding, J.Xiao,Anal Bioanal Chem,385 .1520-1525 (2006).

34. S.Seccia, P.Fidente, D. Montesano, P.Morrica., J Chromatogr A. 1214,115-120 ( 2008)

35. G.Ettiene, R. Bauza, M.R .Plata, A.M .Contento, A .Rios, Electrophor. 33, 2969-2977 (2012)

36. M.E I Badawy, M. A M El-Salam M. Marei , Int J Anal Chem. 16 ID 3640691(2018)

37. J.Ma, L.Hou, G.Wu,L.Wang ,X.Wang,L.Chen , Mater. 13(24), 5729(2020).

38. M.Bali, H.Tlili, International Journal of Environmental Science and Technology.16, 249-258 (2019).

39. N.Rahbar, E. Behrouz, Z.Ramezani. Food Anal Methods.10(7), 2229-2240 (2017).

40. H.Parham, N .Rahbar. Talanta. 80(2),664-669 (2009).

41. N. Rahbar, Z.Ramezani, J.Ghanavati. Chinese Chemical Letters. 27(6), 837-842( 2016)

42. N .Rahbar, P. Abbaszadegan, A .Savarizadeh. Anal Chim Acta . 1026, 117-124 (2018).

43. H .Bagheri, P. Khanipour, S .Asgari. Anal Chim Acta. 934,88-97 2016.

44. X.Tianpeng, L .Jiang, Y .Gong, X. Jun Peng, Y.Qi Feng, Talanta. 132,118-125 (2015).

45. M. Abbas, S. Kaddour, M .Trari. J Ind Eng Chem. 20, 745-751( 2014).

46. B .Kakavandi, R . Rezaei Kalantary, M .Farzadkia, A H. Mahvi, A. Esrafili, A. Azari, A R . Yari, A B. Javid J Environ Health Sci Eng.12,115(2014).

47. H K. Boparai, M. Joseph, D M. O'Carroll, J Hazard Mater. 186(1),458-465(2011).

48. X.Liu, L.Zhang. Int J Biol Macromol. 79,110-117 (2015).

49. N. Rahbar, A.Jahangiri, S .Boumi, M J. Khodayar, Jundishapur J Nat Pharm Prod, 9(2) .e15913 (2014).

50. C.Bertagnolli, M. Gurgel Carlos da Silva, E. Guibal, Chem Eng J. 237,362-371 (2014).

51. G Z. Kyzas, N A .Travlou, E A .Deliyanni, Colloids and surfaces B, Biointerfaces. 113, 467-476 (2014). 


\section{Caption to the figures:}

Fig. 1: Molecular structure of Imidacloprid.

Fig. 2: UV-Vis spectra of $20 \mathrm{mg} \mathrm{L}^{-1} \mathrm{IMCP}$ solution before (a) and after (b) exposure to the adsorbent.

Fig. 3: FESEM images of (A) $\mathrm{Fe}_{3} \mathrm{O}_{4}$ nanoparticles and (B) $\mathrm{Fe}_{3} \mathrm{O}_{4} / \mathrm{CuO} / \mathrm{AC}$ nano composite. (C) The EDX spectra of the adsorbent.

Fig. 4: (A) FTIR spectra of a) $\mathrm{Fe}_{3} \mathrm{O}_{4}$ nanoparticles b) $\mathrm{Fe}_{3} \mathrm{O}_{4} / \mathrm{CuO} / \mathrm{AC}$, c) $\mathrm{Fe}_{3} \mathrm{O}_{4} / \mathrm{CuO} / \mathrm{AC} / \mathrm{IMCP}$, (B) XRD pattern of the adsorbent, and (C) VSM magnetization curves of $\mathrm{Fe}_{3} \mathrm{O}_{4}$ nanoparticles (a) and $\mathrm{Fe}_{3} \mathrm{O}_{4} / \mathrm{CuO} / \mathrm{AC}$ nanocomposite (b).

Fig. 5: The influence of a) $\mathrm{pH}$ and b) the adsorbent amount on the removal efficiency of IMCP.

Fig. 6: The effect of contact time on the removal efficiency (a), and the kinetic models and experimental data (b) for the IMCP adsorption on $\mathrm{Fe}_{3} \mathrm{O}_{4} / \mathrm{CuO} / \mathrm{AC}$ nanocomposite.

Fig. 7: The effect of initial IMCP concentration on the removal efficiency (a), and the isotherm models and experimental data (b) for the IMCP adsorption on $\mathrm{Fe}_{3} \mathrm{O}_{4} / \mathrm{CuO} / \mathrm{AC}$ nanocomposite.

Rahbar N, Ramezani Z, Ghanavati J. CuO-nanoparticles modified carbon paste electrode for square wave 
Formulations and River Water Samples. International Journal of Analytical Chemistry. 2016;Article ID 5138491. Meghdad Pirsaheb NF, Saide Pourhaghighat, Mojtaba Shamsipur, Kiomars, Sharafi. Simultaneous determination 4. of imidacloprid and diazinon in apple and pear samples using sonication and dispersive liquid-liquid microextraction.

LWT - Food Science and Technology. 2015;60 825-31.

Cao X, Liu G, She Y, Jiang Z, Jin F, Jin M, et al. Preparation of magnetic metal organic framework composites for 5. the extraction of neonicotinoid insecticides from environmental water samples. RSC Advances. 2016;6(114):113144-51. Mahramanlioglu MZaM. Adsorption of Imidacloprid on Powdered Activated Carbon and Magnetic Activated 6.

Carbon. Chem Biochem Eng Q (Chemical and Biochemical Engineering Quarterly). 2011;25:55-63.

Socias-Viciana M, Gonzalez-Pradas E, Saifi M, Urena-Amate MD, Flores-Cespedes F, Fernandez-Perez M. The 7. potential removal of imidacloprid from water by heat-treated kerolites. Pest management science. 2003

Oct;59(10):1162-8. PubMed PMID: 14561075.

Tapparo A, Marton D, Giorio C, Zanella A, Solda L, Marzaro M, et al. Assessment of the environmental exposure 8. of honeybees to particulate matter containing neonicotinoid insecticides coming from corn coated seeds. Environmental science \& technology. 2012 Mar 6;46(5):2592-9. PubMed PMID: 22292570. Lopez-Antia A, Ortiz-Santaliestra ME, Mougeot F, Mateo R. Imidacloprid-treated seed ingestion has lethal effect 9. on adult partridges and reduces both breeding investment and offspring immunity. Environmental Research. 2015;136:97-107.

Morrissey CA, Mineau P, Devries JH, Sanchez-Bayo F, Liess M, Cavallaro MC, et al. Neonicotinoid contamination 10. of global surface waters and associated risk to aquatic invertebrates: A review. Environment International. 2015;74:291-

303.

Van Dijk TC, Van Staalduinen MA, Van der Sluijs JP. Macro-invertebrate decline in surface water polluted with 11. imidacloprid. PloS one. 2013;8(5):e62374. PubMed PMID: 23650513. Pubmed Central PMCID: 3641074.

Daraghmeh A, Shraim A, Abulhaj S, Sansour R, Ng JC. Imidacloprid residues in fruits, vegetables and water 12. samples from Palestine. Environmental geochemistry and health. 2007 Feb;29(1):45-50. PubMed PMID: 17131080. Starner K, Goh KS. Detections of the neonicotinoid insecticide imidacloprid in surface waters of three 13. agricultural regions of California, USA, 2010-2011. Bull Environ Contam Toxicol. 2012 Mar;88(3):316-21. PubMed PMID: 22228315.

Weston DP, Chen D, Lydy MJ. Stormwater-related transport of the insecticides bifenthrin, fipronil, imidacloprid, 14. and chlorpyrifos into a tidal wetland, San Francisco Bay, California. Science of The Total Environment. 2015;527-528:18-

Hui Ding1 RWWLSCWJZ7XW. A spherical metal-organic coordination polymer for the microextraction

of neonicotinoid insecticides prior to their determination by HPLC. Microchimica Acta. 2019.

Velizarov S, Crespo JoG, Reis MA. Removal of inorganic anions from drinking water supplies by membrane 16. bio/processes. Reviews in Environmental Science and Bio/Technology. 2005;3(4):361-80.

Charles J, Bradu C, Morin-Crini N, Sancey B, Winterton P, Torri G, et al. Pollutant removal from industrial 17. discharge water using individual and combined effects of adsorption and ion-exchange processes: Chemical abatement. Journal of Saudi Chemical Society. 2016;20(2):185-94.

Pohl A. Removal of Heavy Metal lons from Water and Wastewaters by Sulfur-Containing Precipitation Agents. 18. Water, Air, \& Soil Pollution. 2020;231(10).

Sun Y, Zhou S, Chiang P-C, Shah KJ. Evaluation and optimization of enhanced coagulation process: Water and 19. energy nexus. Water-Energy Nexus. 2019;2(1):25-36.

Zhao Z, An H, Lin J, Feng M, Murugadoss V, Ding T, et al. Progress on the Photocatalytic Reduction Removal of 20. Chromium Contamination. Chemical record. 2019 May;19(5):873-82. PubMed PMID: 30426677.

Rodríguez-Castillo G, Molina-Rodríguez M, Cambronero-Heinrichs JC, Quirós-Fournier JP, Lizano-Fallas V, 21. Jiménez-Rojas C, et al. Simultaneous removal of neonicotinoid insecticides by a microbial degrading consortium: Detoxification at reactor scale. Chemosphere. 2019;235:1097-106.

Hamadi NK, Sri S, Chen XD. Adsorption of Paraquat dichloride from aqueous solution by activated carbon 22. derived from used tires. Journal of hazardous materials. 2004 Aug 9;112(1-2):133-41. PubMed PMID: 15225939.

Azari A, Kakavandi B, Kalantary RR, Ahmadi E, Gholami M, Torkshavand Z, et al. Rapid and efficient magnetically 23. removal of heavy metals by magnetite-activated carbon composite: a statistical design approach. Journal of Porous Materials. 2015;22(4):1083-96.

Ahmadi M, Foladivanda M, Jaafarzadeh N, Ramezani Z, Ramavandi B, Jorfi S, et al. Synthesis of chitosan zero- 24. valent iron nanoparticles-supported for cadmium removal: characterization, optimization and modeling approach. Journal of Water Supply: Research and Technology - Aqua. 2017;66(2):116-30. 
Omidinasab M, Rahbar N, Ahmadi M, Kakavandi B, Ghanbari F, Kyzas GZ, et al. Removal of vanadium and palladium ions by adsorption onto magnetic chitosan nanoparticles. Environmental science and pollution research international. 2018 Dec;25(34):34262-76. PubMed PMID: 30291614.

Yang J, Dong Y, Li J, Liu Z, Min F, Li Y. Removal of Co(II) from aqueous solutions by sulfonated magnetic multi- 26. walled carbon nanotubes. Korean Journal of Chemical Engineering. 2015;32(11):2247-56.

Jafari AJ, Kakavandi B, Kalantary RR, Gharibi H, Asadi A, Azari A, et al. Application of mesoporous magnetic 27. carbon composite for reactive dyes removal: Process optimization using response surface methodology. Korean Journal of Chemical Engineering. 2016;33(10):2878-90.

Mandal A, Singh N. Optimization of atrazine and imidacloprid removal from water using biochars: Designing 28. single or multi-staged batch adsorption systems. International journal of hygiene and environmental health. 2017 May;220(3):637-45. PubMed PMID: 28433639.

Rodriguez-Castillo G, Molina-Rodriguez M, Perez-Villanueva M, Masis-Mora M, Rodriguez-Rodriguez CE. 29. Removal of Two Neonicotinoid Insecticides and Mineralization of (14)C-Imidacloprid in Biomixtures. Bull Environ Contam Toxicol. 2018 Jul;101(1):137-43. PubMed PMID: 29858622.

Rodriguez-Castillo G, Molina-Rodriguez M, Cambronero-Heinrichs JC, Quiros-Fournier JP, Lizano-Fallas V, 30. Jimenez-Rojas C, et al. Simultaneous removal of neonicotinoid insecticides by a microbial degrading consortium: Detoxification at reactor scale. Chemosphere. 2019 Nov;235:1097-106. PubMed PMID: 31561300.

Gonzalez T, Dominguez JR, Correia S. Neonicotinoids removal by associated binary, tertiary and quaternary 31. advanced oxidation processes: Synergistic effects, kinetics and mineralization. Journal of environmental management.

2020 May 1;261:110156. PubMed PMID: 32148258.

Daneshvar N, Aber S, Rasoulifard AKaMH. Investigation of adsorption kinetics and isotherms of imidacloprid as a

pollutant from aqueous solution by adsorption onto industrial granular

activated carbon. Journal of Food, Agriculture \& Environment Vol(3\&4) : . 2007;5 425 - 9. HIROTAKA OBANA MO, KAZUHIKO AKUTSU,, YOKO KITAGAWA ASH. Determination of Neonicotinoid Pesticide 33.

Residues in

Vegetables and Fruits with Solid Phase Extraction and Liquid

Chromatography Mass Spectrometry. J Agric Food Chem 2003;51:2501-5. Xiao QZYDJ. Sensitive determination of thiamethoxam, imidacloprid 34 .

and acetamiprid in environmental water samples with solid-phase extraction packed with multiwalled carbon nanotubes prior

to high-performance liquid chromatography. Anal Bioanal Chem. 2006;385:1520-5. Seccia S, Fidente P, Montesano D, Morrica P. Determination of neonicotinoid insecticides residues in bovine milk 35. samples by solid-phase extraction clean-up and liquid chromatography with diode-array detection. Journal of chromatography A. 2008 Dec 19;1214(1-2):115-20. PubMed PMID: 19004450.

Ettiene G, Bauza R, Plata MR, Contento AM, Rios A. Determination of neonicotinoid insecticides in 36. environmental samples by micellar electrokinetic chromatography using solid-phase treatments. Electrophoresis. 2012

Oct;33(19-20):2969-77. PubMed PMID: 22997021.

Mohamed E. I. Badawy MAME-N, and Abd El-SalamM.Marei. Development of a Solid-Phase Extraction (SPE) 37.

Cartridge

Based on Chitosan-Metal Oxide Nanoparticles (Ch-MO NPs) for

Extraction of Pesticides from Water and Determination by HPLC. International Journal of Analytical Chemistry. 2018;2018:ID 3640691.

Jiping Ma 1, Liwei Hou 1, GegeWu 1, Liyan Wang 2, Xiaoyan Wang 2,3 and Lingxin Chen. Multi-Walled Carbon 38. Nanotubes for Magnetic Solid-Phase Extraction of Six Heterocyclic Pesticides in Environmental Water Samples Followed

HPLC-DAD Determination. Materials. 2020; 13:5729.

Bali M, Tlili H. Removal of heavy metals from wastewater using infiltration-percolation process and adsorption 39. on activated carbon. International Journal of Environmental Science and Technology. 2018;16(1):249-58.

Rahbar N, Behrouz E, Ramezani Z. One-Step Synthesis of Zirconia and Magnetite Nanocomposite Immobilized 40. Chitosan for Micro-Solid-Phase Extraction of Organophosphorous Pesticides from Juice and Water Samples Prior to Gas Chromatography/Mass Spectroscopy. Food Analytical Methods. 2017;10(7):2229-40. 
Parham H, Rahbar N. Solid phase extraction-spectrophotometric determination of fluoride in water samples

Rahbar N, Abbaszadegan P, Savarizadeh A. A sensitive fluorescent sensing strategy for nanomolar levels of 42. metformin using graphitic carbon nitride nanosheets as nanofluoroprobe. Analytica chimica acta. 2018 Oct 5;1026:117-

24. PubMed PMID: 29852987.

Bagheri H, Khanipour P, Asgari S. Magnetic field assisted $\mu$-solid phase extraction of anti-inflammatory and loop 43. diuretic drugs by modified polybutylene terephthalate nanofibers. Analytica chimica acta. 2016.

Peng XT, Jiang L, Gong Y, Hu XZ, Peng LJ, Feng YQ. Preparation of mesoporous ZrO2-coated magnetic 44. microsphere and its application in the multi-residue analysis of pesticides and PCBs in fish by GC-MS/MS. Talanta. 2015 Jan;132:118-25. PubMed PMID: 25476287.

Abbas M, Kaddour S, Trari M. Kinetic and equilibrium studies of cobalt adsorption on apricot stone activated 45. carbon. Journal of Industrial and Engineering Chemistry. 2014;20(3):745-51.

Kakavandi B, Rezaei Kalantary, R., Farzadkia, M., Mahvi, A. H.,, Esrafili A, Azari, A., Yari, A. R. \& Javid, A. 46. chromium ( $\mathrm{VI}$ ) removal using activated carbon modified by zero valent iron and silver bimetallic nanoparticles. Journal of

Environmental Health Science and Engineering. 2014; 12: 1-10.

Boparai HK, Joseph M, O'Carroll DM. Kinetics and thermodynamics of cadmium ion removal by adsorption onto 47. nano zerovalent iron particles. Journal of hazardous materials. 2011 Feb 15;186(1):458-65. PubMed PMID: 21130566.

Liu X, Zhang L. Insight into the adsorption mechanisms of vanadium(V) on a high-efficiency biosorbent (Ti-doped 48. chitosan bead). International journal of biological macromolecules. 2015 Aug;79:110-7. PubMed PMID: 25940529. Rahbar; N, Jahangiri; A, Boumi; S, Khodayar MJ. Mercury Removal From Aqueous Solutions With Chitosan- 49. Coated Magnetite Nanoparticles Optimized Using the Box-Behnken Design Jundishapur J Nat Pharm Prod 2014;9:e15913

Bertagnolli C, da Silva MGC, Guibal E. Chromium biosorption using the residue of alginate extraction from 50. Sargassum filipendula. Chemical Engineering Journal. 2014 2/1/;237(0):362-71. Kyzas GZ, Travlou NA, Deliyanni EA. The role of chitosan as nanofiller of graphite oxide for the removal of toxic 51. mercury ions. Colloids and surfaces B, Biointerfaces. 2014 Jan 1;113:467-76. PubMed PMID: 23973000. 
Figures

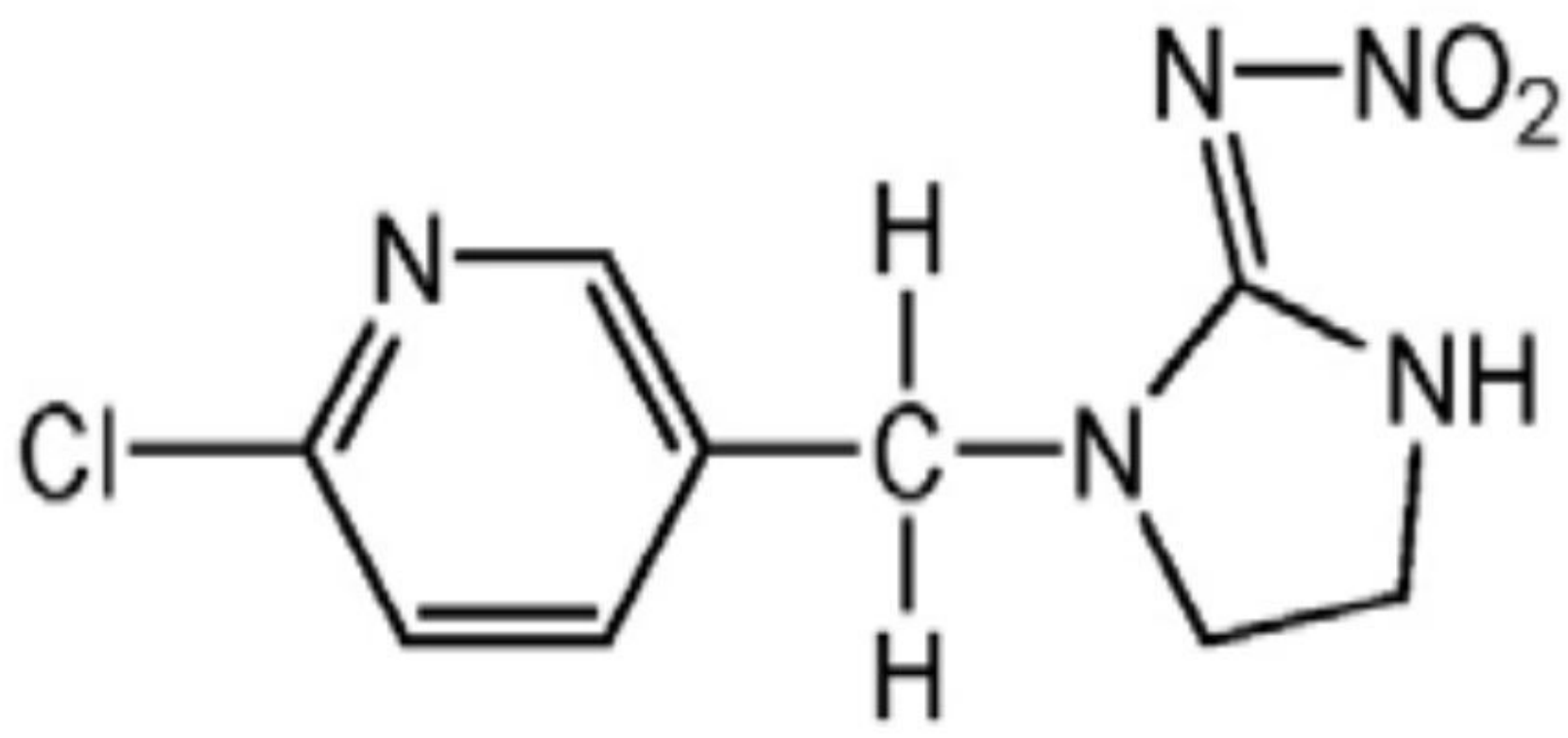

Figure 1

Molecular structure of Imidacloprid. 


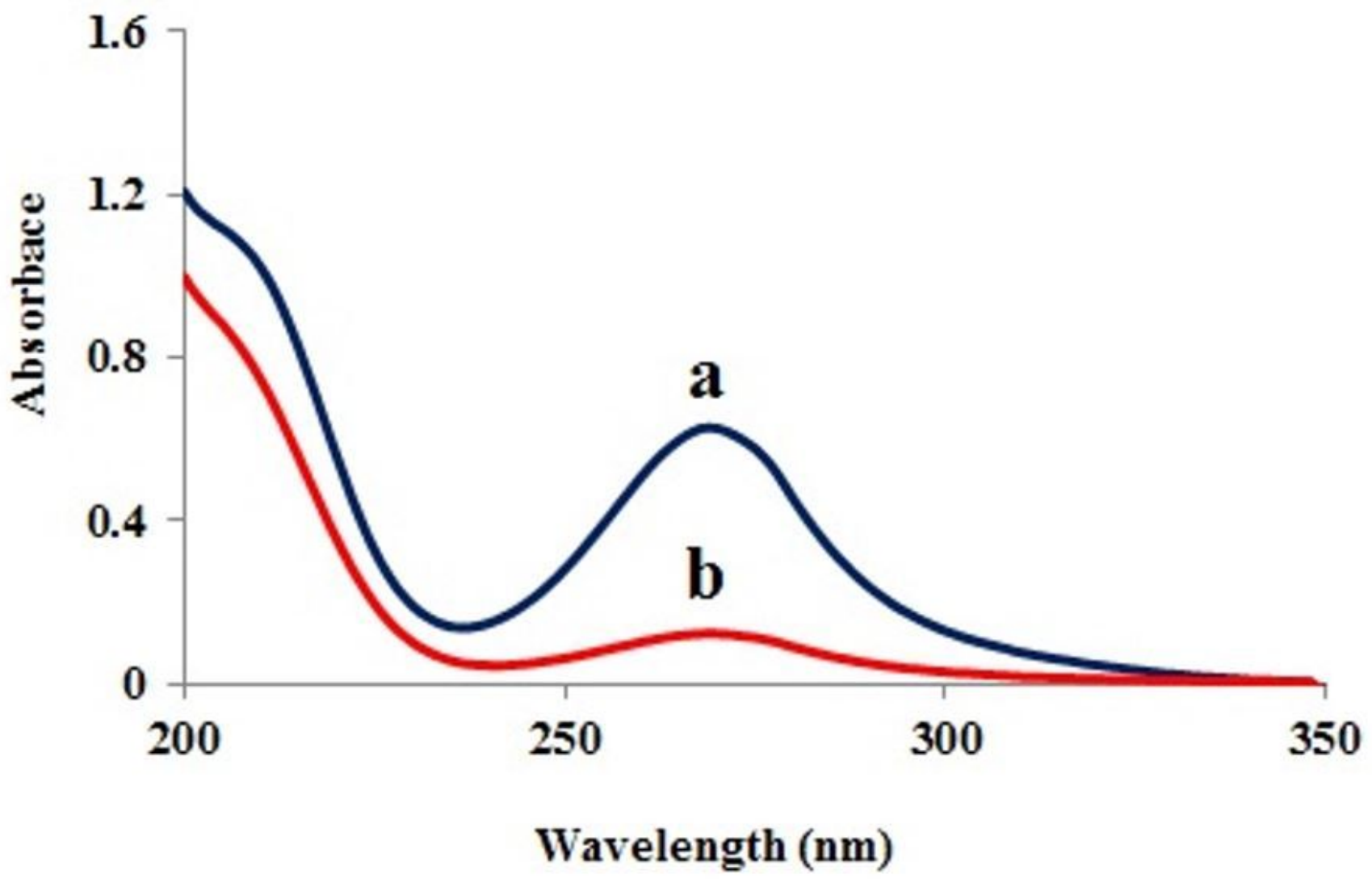

Figure 2

UV-Vis spectra of $20 \mathrm{mg} \mathrm{L-1} \mathrm{IMCP} \mathrm{solution} \mathrm{before} \mathrm{(a)} \mathrm{and} \mathrm{after} \mathrm{(b)} \mathrm{exposure} \mathrm{to} \mathrm{the} \mathrm{adsorbent.}$ 

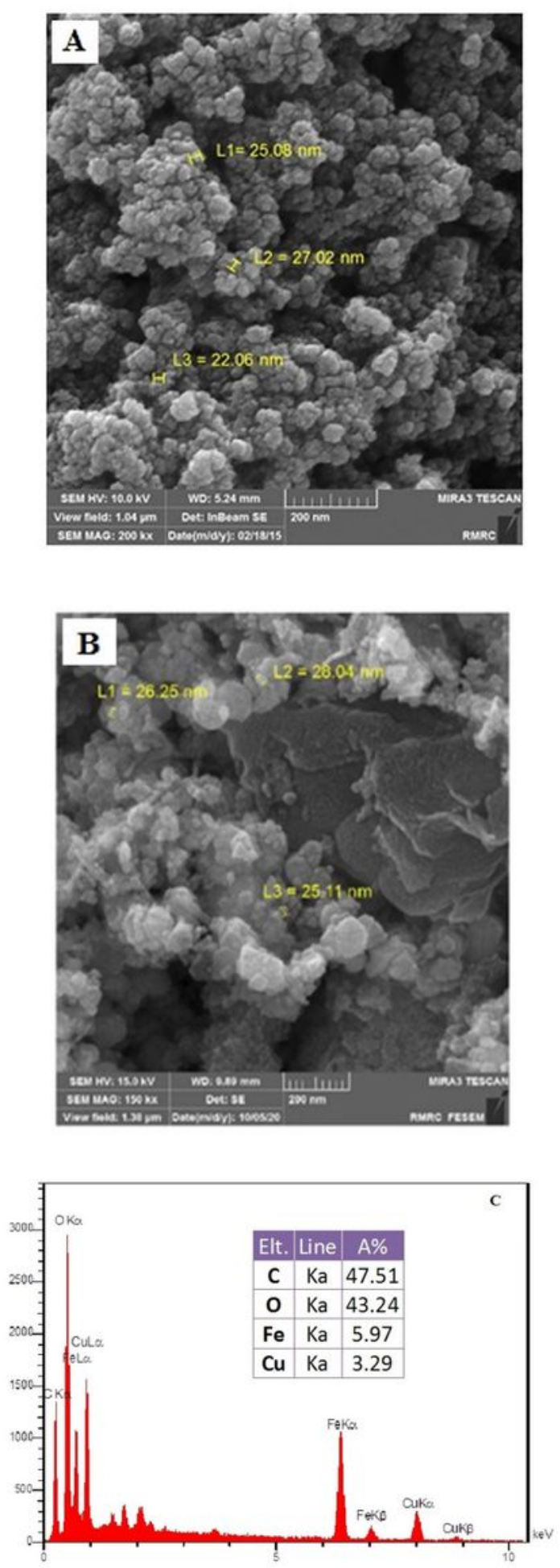

Figure 3

FESEM images of (A) Fe304 nanoparticles and (B) Fe304/CuO/AC nano composite. (C) The EDX spectra of the adsorbent. 

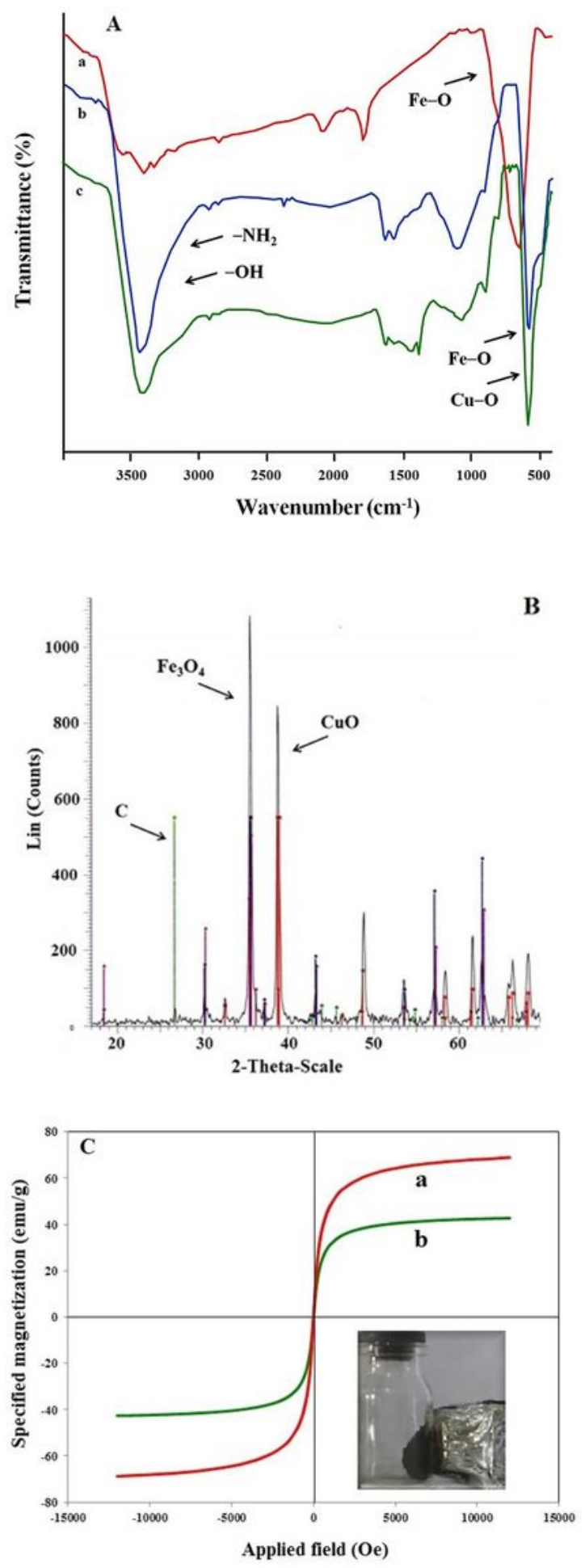

Figure 4

(A) FTIR spectra of a) Fe304 nanoparticles b) Fe304/CuO/AC, c) Fe304/CuO/AC/IMCP, (B) XRD pattern of the adsorbent, and (C) VSM magnetization curves of Fe304 nanoparticles (a) and Fe304/CuO/AC nanocomposite (b). 


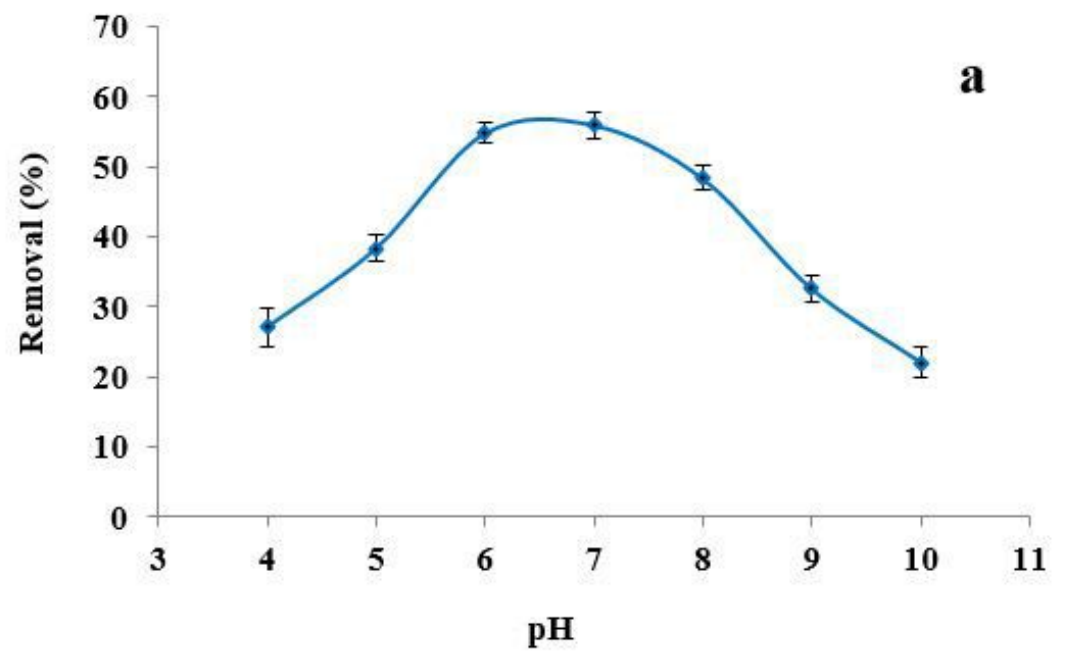

a

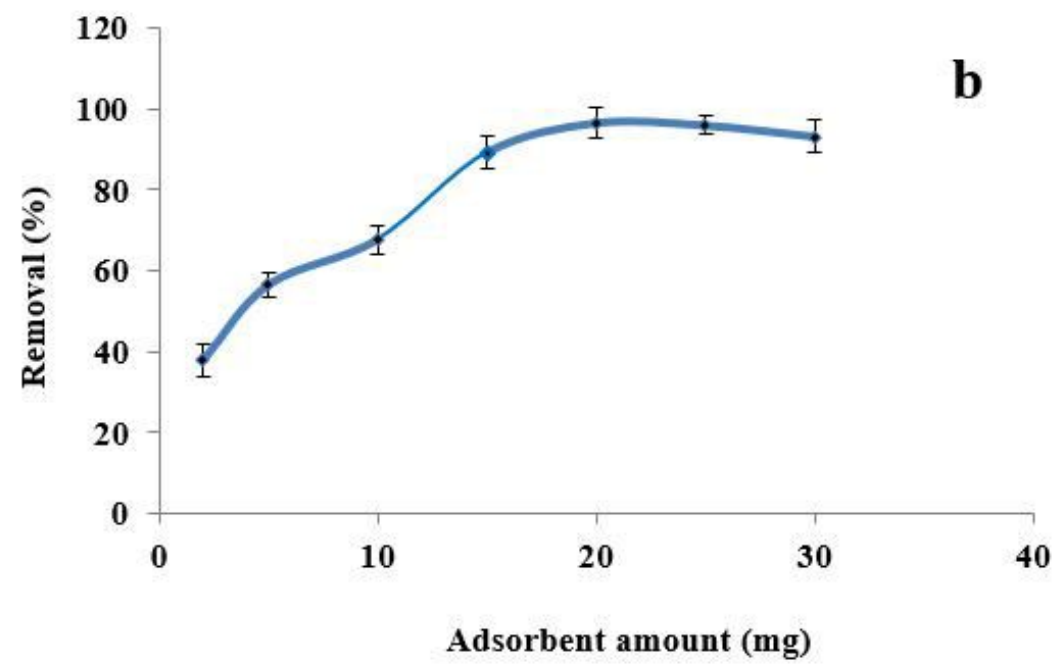

b

Figure 5

The influence of a) $\mathrm{pH}$ and b) the adsorbent amount on the removal efficiency of IMCP. 


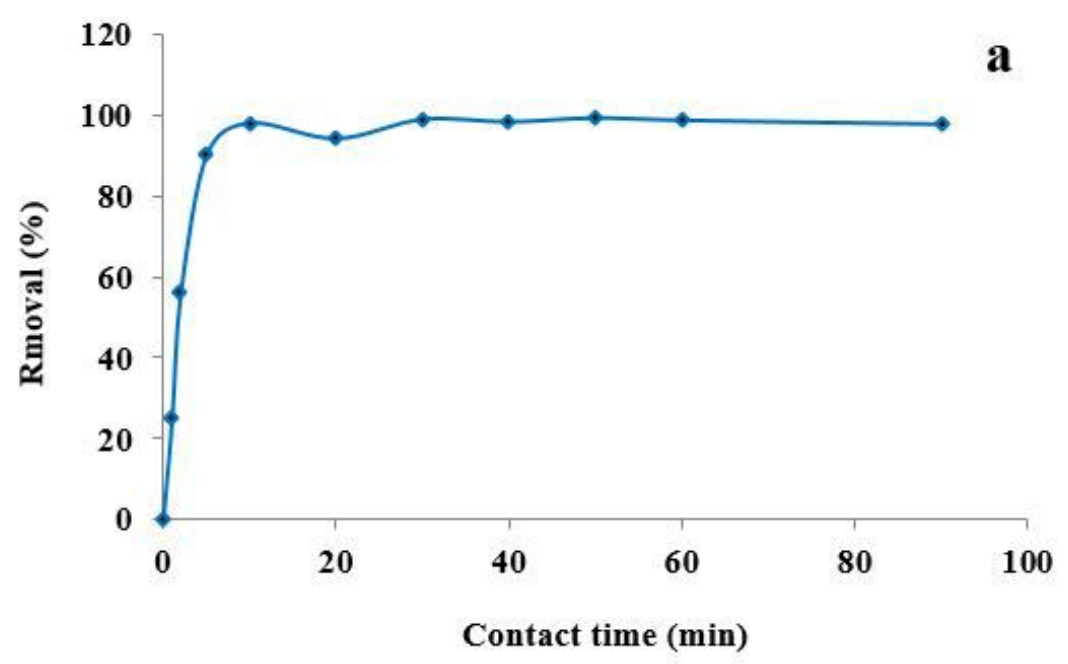

a

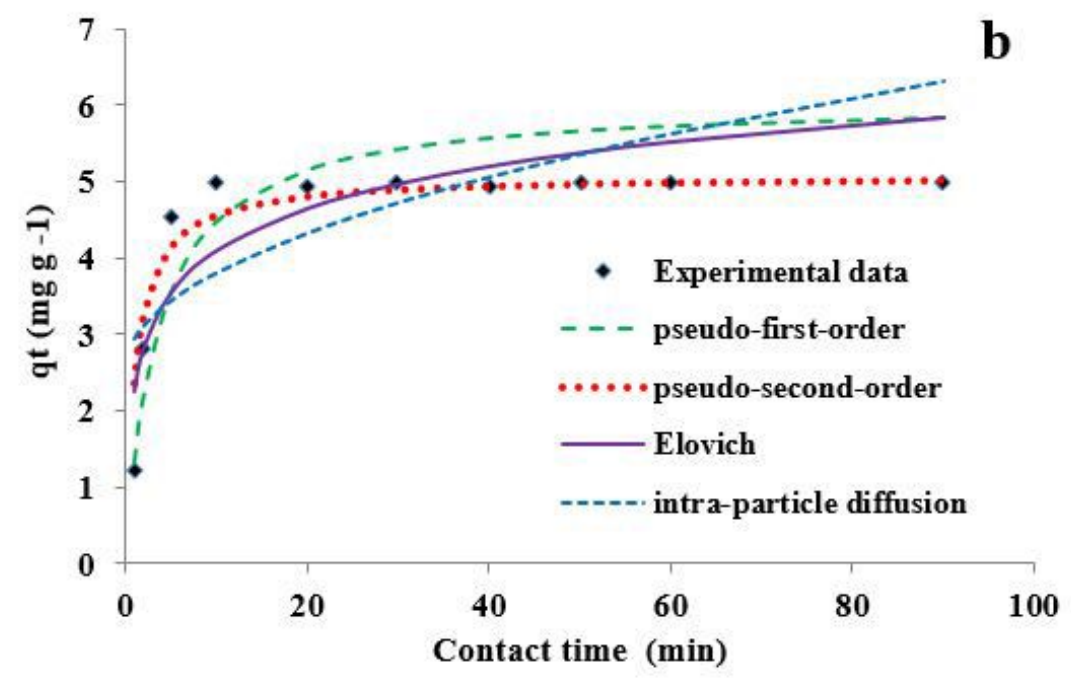

b

Figure 6

The effect of contact time on the removal efficiency (a), and the kinetic models and experimental data (b) for the IMCP adsorption on Fe304/CuO/AC nanocomposite. 


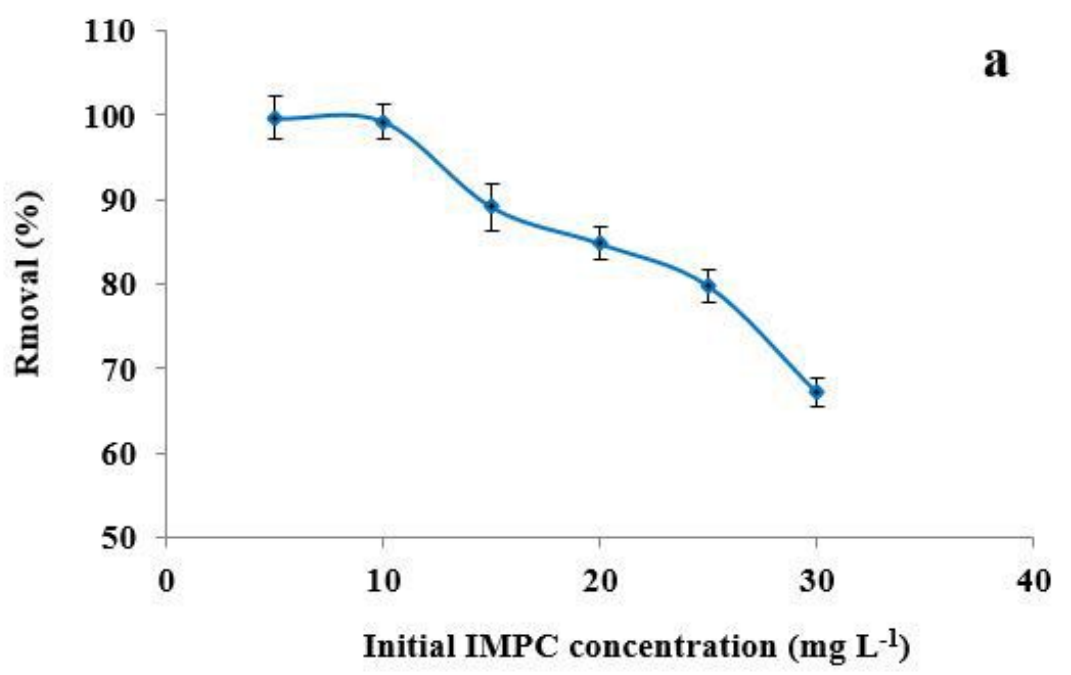

a

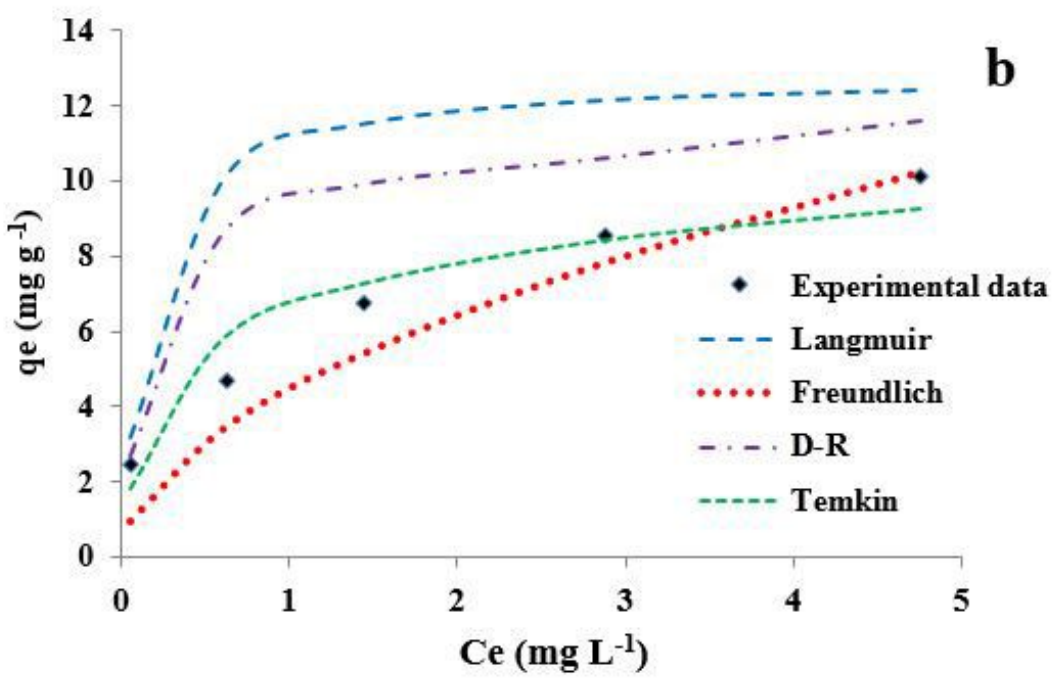

b

Figure 7

The effect of initial IMCP concentration on the removal efficiency (a), and the isotherm models and experimental data (b) for the IMCP adsorption on Fe304/CuO/AC nanocomposite.

\section{Supplementary Files}


This is a list of supplementary files associated with this preprint. Click to download.

- SupplementaryInformation.docx 